\title{
Government Policy in Overcoming Religious Extremism in Indonesia: A Multidisciplinary Review between Public Administration and Psychology
}

\author{
Dana R. Buana1@®, Masayu N. Juwita ${ }^{2}$ \\ ${ }^{1}$ Tomsk State University, Russian Federation, \\ Prospect Lenina 36, Tomsk, Tomsk Oblast, Russian Federation, 634050 \\ ${ }^{2}$ University of Bandar Lampung, \\ Z.A. Pagar Alam Street No.29 Labuhan Ratu, Lampung, Indonesia, 35142 \\ $\bowtie$ dana.riksabuana@gmail.com
}

\begin{abstract}
The development of religious extremism in Indonesia continues to increase every year so that serious attention is needed by the government to deal with religious extremism in Indonesia. Indonesia is an archipelagic country where there are various ethnic groups and religions that coexist. However, the development of religious extremism sometimes becomes a serious problem for the Indonesian people because it can have a negative impact and damage the unity between nations and religions. This research uses literature study. This research method is carried out by reviewing various literatures, both books, newspapers, survey reports, academic journals related to religious extremism in Indonesia. The results show that not all religious extremism has an impact on the emergence of terrorism, but the government still must make the right policies in handling religious extremism that can cause division and affect people's welfare. The policies that have been made by the government are considered appropriate and based on the laws that have been set by the government so that they can have a positive impact in maintaining the unity and integrity of the Indonesian nation.
\end{abstract}

Keywords: government policy, religious extremism, community unity, terrorism, Indonesia

Conflicts of interest: The authors declared no conflicts of interest.

Article history:

The article was submitted on 09.08.2021. The article was accepted on 25.09.2021.

For citation: Buana D.R., Juwita M.N. Government Policy in Overcoming Religious Extremism in Indonesia: A Multidisciplinary Review between Public Administration and Psychology. RUDN Journal of Public Administration. 2021;8(4):423-433. DOI: 10.22363/2312-8313-2021-8-4-423-433

\section{Introduction}

At the beginning of 2021, Indonesia was again shocked by two acts of terror in the name of religion that occurred very close together. The first action took place in Makassar City, South Sulawesi on Sunday, March 28, 2021. A suicide bomb

(C) Buana D.R., Juwita M.N., 2021

(c) () This work is licensed under a Creative Commons Attribution 4.0 International License https://creativecommons.org/licenses/by/4.0/ 
exploded at the Makassar Cathedral Church. The incident began when the perpetrators, who were a couple who had only been married for six months, were about to enter the church. However, because the security officers quickly intercepted, they were unable to carry out their actions inside the church. So, the bomb they were carrying exploded outside the church. As a result of this incident, the couple died and left 20 people injured. A few days later, another act of terrorism occurred in Jakarta. This time, the perpetrator was a woman who attacked the National Police Headquarters with an improvised pistol [1].

One of these acts of terror and other previous terrors that occurred in Indonesia was master minded by JAD (Jamaah Ansharut Daulah). This terrorist group has spread in 19 provinces in Indonesia. Thus, it is possible that there will be further attacks from the group in similar places. Because if you look closely, the places they attack are places of worship and police officers. They attack places of worship because for them, those who disagree with them must be killed. They also attacked the police as a form of resistance to what the police had done to their friends [1].

Not only that, the Executive Board of the Indonesian Ulema Council (MUI) Center for the Handling of Terrorism, Muhammad Najih Arromadloni said that currently the number of people belonging to terrorist groups in Indonesia is very large. No less than 16,000 people belong to terrorist network groups that are ready to carry out acts of terror. In addition to the Jamaah Ansharut Daulah group, other groups that carry out acts of terrorism are Jemaah Islamiah Mujahidin Indonesia Timur (MIT), and Jamaah Ansharut Tauhid (JAT) [2].

Terrorism is rooted in extremism or radicalism in religion. The two concepts can be used synonymously in explaining the tendency to violence in the name of religion [3]. The concept of radicalism or extremism is a mental process in a person or group that adopts religious, social, political, or extreme aspirations to achieve specific goals by justifying the use of indiscriminate violence [4]. Moreover, the construct is excessive in religion, precisely applying belief rigidly and severely to the limits of reasonableness [5]. Extremism can also be defined as an effort that aims to achieve a social goal in various ways, especially extreme movements (acts of violence) [6]. Therefore, to be able to tackle the problem of terrorism in Indonesia, all interested parties must look at the root of terrorism itself, namely extremism. If someone is already at the jihad ideological or terrorist stage, it will be very difficult to overcome, because they are ready to carry out acts of terrorism.

Looking further at extremism, the Government of Indonesia through data from the National Counterterrorism Agency (BNPT) released the results of a national survey on the potential for radicalism this year. The results are quite surprising, namely 85 percent of the millennial generation and generation $\mathrm{Z}$ are vulnerable to being exposed to radicalism. They access the internet like entering the wilderness. When looking for religious content, for example, there is a tendency to accept a preference for religious lectures with a short duration so that they are not accepted in their entirety. In addition, the survey also found a higher potential for radicalism among women than men. Women have $12.3 \%$ potential, while men have $12.1 \%$. Another finding is that the potential for radicalism among urbanites is higher than that of rural people [7]. In fact, many teenagers are found to be members of extremism and terrorism movements [8]. 
From these data, the phenomenon of extremism in Indonesia is quite complex. Many aspects must be considered to overcome this problem. In this study, an approach in public policy will be used from the perspective of Public Administration and Psychology to explain the dynamics of extremism that occurs so that effective prevention can be applied. In addition, the formulation of policies that are right on target by the government must be implemented properly to achieve the goals that have been set.

\section{Public Policy Concept}

According to Chandler and Plano, public policy is the strategic use of existing resources to solve public or government problems. Public policy is a form of intervention carried out continuously by the government for the benefit of disadvantaged groups in society so that they can live, and participate in broad development. The definition of public policy according to Chandler and Plano can be classified as government intervention policy. In this case, the government utilizes various instruments it has to solve public problems [9].

Meanwhile, according to Thomas R. Dye, public policy is said to be what the government does not do or does. The subject of this study is the state. This understanding was further developed and updated by scientists working in the science of public policy. This definition of public policy according to Thomas R. Dye can be classified as a decision (decision making), where the government has the authority to use authoritative decisions, including the decision to let something happen in order to solve a public problem [10].

In additon, according to Anderson, public policies are policies developed by government agencies and officials, where the implications of these policies are:

a) Public policy always has a specific goal or has goal-oriented actions;

b) Public policy contains government actions;

c) Public policy is what the government actually does so is not what it is still intended to do;

d) Public policies taken can be positive in the sense that they are government actions regarding certain issues, or negative in the sense that they are government decisions not to do something;

e) Government policies, at least in a positive sense, are based on laws and regulations that are binding and coercive.

Woll stated that public policy is a number of government activities to solve problems in society, either directly or through various institutions that affect people's lives. The effects of the government's actions are:

a) There are policy choices made by politicians, government employees or others that aim to use public power to influence people's lives.

b) The existence of policy outputs, where policies implemented at this level require the government to make arrangements, budgeting, formation of personnel and make regulations in the form of programs that will affect people's lives.

c) There is a policy impact which is the effect of policy choices that affect people's lives.

This definition of public policy according to Woll can be classified as government intervention (socio-cultural intervention) by utilizing various instruments 
to overcome public problems. This definition can also be classified as a series of work by public officials to solve problems in society [11].

The stages of public policy according to William Dunn are as follows [12]:

a. Agenda Preparation;

b. Policy Formulation;

c. Policy Adoption/ Legitimacy;

d. Policy Assessment/ Evaluation.

One of the functions of politics is to make policies and policies exist because of two factors, namely; there are social problems and changes in power that result in changing policies. Policies can be realized by means of; Making Law Regulations, Planning Activities, Various interventions on the economy/social community. Because the policy is an act and decision of the government, the policy is characterized by power that is dominated by the government and is in accordance with the laws and authorities of the government [13].

\section{Research Methods}

The method used in this research is literature study. This research method is carried out by reviewing various literatures, both books, newspapers, survey reports, theses or dissertations and academic journals related to religious extremism in Indonesia. Library research focuses on finding various theories, laws, propositions, principles, or ideas to analyze and solve research questions. Research questions that will be answered and resolved in the study by reviewing the development of religious extremism that occur in the best and effective way so that problems can be resolved through government policies in Indonesia [14].

\section{Research Results and Discussion Government Policy in Overcoming Extremism in Indonesia}

Indonesia is an archipelagic country that has thousands of islands and various ethnicities in it. This country is a strategic zone in trade and population movement from various countries in the world. Currently, there are 6 recognized religions in Indonesia, namely, Islam, Protestantism, Catholicism, Hinduism, Buddhism, and Confucianism [15]. All religions in Indonesia live side by side and take care of each other. Indonesia is a country known for its tolerance in religion and culture. Religion recognized by this state is highly valued and protected by laws governing religious affairs.

The development of Religious Extremism continues to increase every year in Indonesia so that it needs serious attention from the government in overcoming the existing problems. Religious extremism that continues to occur can have an impact on people's welfare and cause the spread of terrorism networks in Indonesia. Until now, Indonesia has a comprehensive strategy in countering terrorism that combines hard and soft approaches. In relation to the hard approach, Indonesia has issued Law Number 15 of 2003 concerning Countering Terrorism and Law Number 9 of 2013 concerning Prevention and Eradication of Criminal Acts of Terrorism Financing. Furthermore, to strengthen efforts to counter terrorism financing, Indonesia has also ratified a Joint Regulation on the Inclusion of the Identity of Persons and 
Corporations in the List of Suspected Terrorists and Terrorist Organizations and the Immediate Blocking of Funds Owned by Persons or Corporations Listed in the List of Suspected Terrorists and Terrorist Organizations [8].

The State of Indonesia also supports prevention efforts by, among others, implementing UN Security Council Resolutions 1267 (1999) and 1988 (2011) which are in line with Indonesian national law related to countering terrorism financing. On that basis, Indonesia already has a List of Suspected Terrorists and Terrorist Organizations based on the Al-Qaeda Sanctions List and the Taliban List for the asset freezing process [5].

In relation to the soft approach, Indonesia carries out deradicalization and counter-radicalization programs. In this regard, Indonesia through the National Counterterrorism Agency has launched a Blueprint for Deradicalization and established a Deradicalization Center for terrorist convicts. Referring to the Blueprint document, the deradicalization program includes rehabilitation, reintegration, and re-education for terrorist prisoners by empowering religious leaders and psychologists to provide counter-narratives [7].

Religion is often used as a tool for terrorists to launch their actions in destroying the nation and destroying the integrity of the country. However, in Indonesia, the Government has issued a policy in the form of strict sanctions for terrorists who are very dangerous for the country. Although not all religious extremism can lead to terrorist movements or lead to terrorism, religious extremism is very risky and can become thoughts that lead to terrorism, violence, and so on [8].

One of the toughest punishments for terrorists in Indonesia is the death penalty which is regulated by the Law of the Republic of Indonesia. This punishment has provided a deterrent effect on terrorists in Indonesia who are under the guise of religion. Religious extremism that gives rise to radical understanding is sometimes very inconvenient for the government, especially giving negative doctrines to the government and society [1].

Firm action by the government has been implemented to date and various policies have been taken to prevent the development of religious extremism in Indonesia. One of the policies to prevent religious extremism in Indonesia is to provide an understanding to the public about the importance of Pancasila ideology and the value of national unity. This will have a good impact on the younger generation to avoid religious extremism in Indonesia [2].

\section{Religious Extremism in General According to Psychological Approach}

As it is known that extremism is the seed of the terrorism movement, but research conducted by Borum $[16 ; 17]$ states otherwise. The study states that the relationship between extremism or radicalism and terrorist activity is not simple. People with radical beliefs (there are many of them in the world) do not commit terrorist acts; but the opposite is also true: terrorists do not always adhere to radicalism [17]. This research is reinforced by the findings which state that $99 \%$ of people with radical views will never move towards terrorist activities, and many have committed acts of terrorism without having radical ideas [18]. 
This contradictory situation can occur because the terms radicalism, extremism, and fundamentalism are used synonymously. Radicalism and extremism can be used interchangeably, because the two constructs describe the mental process of a person who does not use common sense in religion, and is ready to do anything even with violence to achieve certain goals for the truth of the religion he believes in. This is different from fundamentalism. Fundamentalism is how an individual feels belonging to areligion and thus considers that his belief is the rightest faith and ready to defend it. They argue that violence is not merely a way out to protect religion but instead promotes tolerance and peace [3]. So, people who hold radical views and do not have a direction of terrorist activity should be said to be fundamentalists instead of radicalists.

With this classification, the prevention of criminal acts of terrorism can be carried out as early and as early as possible. And it can also prevent wrong judgments on someone who is fanatic in their religion, but they prioritize moral and human values and avoid extremism [19]. The opposite condition will be very bad, where a person who carries out acts of terrorism without having radical ideas or only uses religion for personal or group interests or for certain politics. Because usually the leadership of the terrorist movement is filled by people who only use religion for their interests, even though they are not religious themselves. This person will use extremists to carry out acts of terror to achieve their goals.

There are several aspects that cause a person to be extreme in religion. The first aspect is religious identity. Religious identity is like having two sides of a coin, in one side it can overcome a feeling of uncertainty, but the other side religious identity can also trigger extremism because of religious zeal in overcoming personal uncertainty [20]. Feeling of uncertainty comes up because of the need to think about ourselves, who we are, how we behave, who is other people, how they behave, and how our existence and this nature. The best way to reduce uncertainty feelings is to self-identified with a group, especially an entitative group [21]. A person who identifies himself to religious groups can obtain a sense of stability because religion offers eternal group membership, gives absolute truth, satisfies the need for belonging, to reduce existential anxiety [22].

The second aspect is group favouritism. This construct states that individuals will tend to justify their groups [23]. In other words, a person will be more likely to think that another religion or group is wrong or inferior. This condition can occur when a person is not yet in the high phase of religious identity. Because when a person is already in a high phase, individuals successfully achieve inner harmony between the rational and emotional aspects of religion's perception and can simultaneously function. They do not feel the need for an aggressive reaction in a religious conflict, may show interest in other religions and even learn the value of wisdom from the teachings of other religions [24].

The third aspect is the system of religious teaching. Today, religious teaching is generally dogmatic, and Islam is no exception. This dogmatic teaching makes religious people dull their critical thinking power and common sense to interpret the essence of something. Religious teachings prioritize laws or Sharia. The teachings conveyed about sharia are indeed true and can guide people towards goodness, but teaching about religion is not that simple, because it will dull the 
exploration of humans who have extraordinary gifts through reason and reason. can easily be brainwashed to be able to carry out prohibited and immoral movements such as acts of terrorism [8].

The fourth aspect is poverty and unhappiness. Individuals whose lives are not prosperous will be very difficult to think critically and openly, because they will focus more on improving their standard of living which is more or less related to the fulfillment of materialistic daily life, so it will automatically be difficult to have access to many things. reading references to be able to help expand the mind, and build self-character, or spend a lot of time studying a science and interpreting its essence. So that they will be more easily infiltrated by extreme thoughts that can lead to acts of terrorism [25].

It's not just unhappiness, unhappiness (not just based on material things) will also make people aggressive [26]. This is because a person is disappointed in his life, feels angry and wants to vent on an object known as catharsis. In more severe cases these feelings can lead a person to extreme actions, then religion will be used as a tool to vent it by joining a terror group. So, consciously, or not, religion is only to satisfy the negative desires that exist within [26].

\section{Women and Extremism}

The view in seeing acts of terrorism is often identified with masculinity or actions that are entirely carried out by men, but in fact based on the data presented in the introduction states that the potential for women to be exposed to radicalism is greater than men. This is very dangerous because there are still many who ignore this phenomenon. The female terrorists succeeded in fulfilling the purpose assigned to her. In addition, they can work more freely because of the lack of tight control over their actions [26]. According to Europol data, a quarter of those arrested for terrorist activity in 2016 were women [27].

Ignoring the issue of the radicalization of women and their involvement in terrorist activities is based on the erroneous idea that women are incapable of cruel acts (how can the person who gave life destroy them in the most barbaric way) [28]. According to this misunderstanding, women, in extreme cases, play a secondary role in terrorist organizations (terrorist wives and mothers; even in certain cases women play very important roles -such as raising children to become terrorists). The facts also show that women can perform the tasks performed by male terrorists if under certain circumstances the man has been exposed or prone to failure [29].

In terrorist groups, women fulfill a number of social roles: they are informants, specialists in developing propaganda strategies, recruiters, managers, qualified specialists, translators, objects of sexual decoys, etc. So, the involvement of women by terrorist organizations is a new strategy to reach a wider audience wider [29].

The cause of a woman especially in Indonesia being exposed to extremism to acts of terrorism is the desire to change the position and status of the woman herself in society. As is known, Indonesia is still thick with patriarchal culture like most other Asian countries. With this thick culture, a woman sometimes wants to free herself from these shackles. One way to get out of these shackles is to join the 
movement of extremism to terrorism. By joining these groups, women can channel their aspirations and desires to be able to change their status both in economic, social, and political terms [30]. This is reinforced by terrorist groups which are characterized by: rigid hierarchical structure; strong leadership, homogeneous viewpoints, and high adherence to the group. With the characteristics of such a group, a woman will feel that the group can fulfill her aspirations because she feels marginalized based on a patriarchal culture [31].

\section{Teenager and Extremism}

One of the most significant deterrents to acts of terrorism is to break the chain of recruiting members that originate from the idea of extremism. It is very alarming to know that many of the new members of the terrorism movement are teenagers, even those who commit suicide bombings [32]. Many adolescents who are trapped in extremist movements or even to terrorism because ideas of extremism easily infiltrate them [31]. Besides, the youth who join the terrorist act is inseparable from theexpertise and ingenuity of the leaders of the terrorist movement in recruiting members or people who are deemed worthy of being recruited and nurtured to become terrorists [7].

There are several aspectswhy teenager is more easily recruited or exposed to terrorism movements in the psychological approach. First is the search for selfidentity. Entering adolescence, a human will start looking for his identity in life, such as what he likes, what is potential in him, or what he wants to be when he grows up. This period is a transition between the world of children and adults. Biologically a human at this stage has begun to enter the adult stage, but psychologically the age of adolescence is still not fully ready to be given the responsibility like an adult. At this stage, a teenager will try many things to find out their identity. Usually, they will pass it with friends who have the same commitment in a group. Their relationship within the group is remarkably close, so they have high solidarity with fellow group members [8].

Harter stated that adolescents who were too disappointed over their inconsistent portrayals would act out ofcharacter to improve their image or get recognition from parents or peers. Children at this age are prone to do harmful things to find their identity [7].

Based on Erickson's theory of social development, people who have problems at this stage will experience identity confusion. Adolescents can cause this circumstance do not get support from family or community, do not have a special relationship closeness or lack of exploring the potential that exists within [8]. Therefore, that condition can be exploited by terrorists to recruit new members by making teens feel understood, recognized, and valued. These terrorists understand the psychological state of adolescents, so they more often recruit teenagers because they are easier to be brainwashed.

The next aspects are cognition and emotion. Based on the cognitive and emotional concepts, adolescents still do not have the maturity of stable thinking and emotions, so they do not yet have a steady self-attitude and their views on the world about moral and ethical values are still extremely limited [1]. By understanding the 
cognitive and emotional conditions of unstable teenagers, the idea of thoughts and movements of extremism that can lead to terrorism can easily poison them.

\section{Conclusion}

Based on this description, it can be concluded that the Government of Indonesia has taken appropriate steps in handling religious extremism in Indonesia which can affect the welfare of the community. The Indonesian government has made various policies including regulations and laws that can prevent the emergence of terrorism in Indonesia. When viewed in terms of government policies, in Indonesia there are many regulations that emphasize the prohibition of extremist movements in religion and the prevention of the emergence of terrorist movements that can harm the nation and state.

Although not all religious extremism is the root of terrorism or radicalism, it can still have a negative impact on people's thinking and damage the values of the unity of the Indonesian nation. Knowledge of the value of nationalism is needed to maintain the integrity of the nation and state. In addition, the younger generation should understand the values of Pancasila which is the ideology of the Indonesian nation so that they can maintain the integrity and unity of the nation. The policies of the Indonesian government have a good impact on preventing religious extremism, terrorism, and radicalism so that the integrity of the nation can be maintained and welfare for the community can be realized in accordance with the goals of the founders of the Indonesian nation.

\section{REFERENCES}

1. Hilmy A. Aksi Terorisme Di Indonesia Belum Selesai. Momentum. URL: https://lpmmomentum.com/2021/04/aksi-terorisme-di-indonesia-belum-selesai/. Accessed: 28.04.2021 (In Indon.).

2. Maaruf E. 16.000 Orang Gabung Organisasi Teroris, Siap Melakukan Aksi Teror. SINDONEWS.COM. URL: https://nasional.sindonews.com/read/464560/14/16000-oranggabung-organisasi-teroris-siap-melakukan-aksi-teror-1624457173. Accessed: 23.06.2021 (In Indon.).

3. Buana D.R., Lukyanov O.V. Understanding Violent Religious Behavior in Indonesia: From the Concept to the Prevention. Jurnal Cita Hukum (Indonesian Law Journal). 2020;8(1):1-16. DOI: https://doi.org/10.15408/jch.v8i1.15003

4. Wilner A.S., Dubouloz C.-J. Home Grown Terrorism and Transformative Learning: an Interdisciplinary Approach to Understanding Radicalization. Global Change, Peace \& Security. 2010;22(1):33-51. DOI: https://doi.org/10.1080/14781150903487956

5. Yunus A.F Radikalisme, Liberalisme dan Terorisme: Pengaruhnya Terhadap Agama Islam. Jurnal Studi Al-Qur'an. 2017;13(1):76-94. DOI: https://doi.org/10.21009/JSQ.013.1.06 (In Indon.).

6. Davydov D., Khlomov K. Questionnaire for the Diagnosis of Violent Extremism Attitudes. SSRN Electronic Journal. 2017. DOI: https://doi.org/10.2139/ssrn.3069902

7. Mohammad C. Survei BNPT: 85 Persen Milenial Rentan Terpapar Radikalisme. INewsBali.Id. URL: https://bali.inews.id/berita/survei-bnpt-85-persen-milenial-rentan-terpaparradikalisme/2. Accessed: 17.12.2020 (In Indon.).

8. Buana D.R. Teenagers and Terrorism in Indonesia; How To Understanding and Preventing. Journal of Critical Reviews. 2020;7(19):2960-2964.

9. Setiawan R. Peranan Etika Aparatur Sipil Negara Dalam Pelayanan Publik Pada Dinas Kependudukan Dan Catatan Sipil (Disdukcapil) Kota Bandar Lampung. Jurnal e-JKPP. 2016;2(2):46-57 (In Indon.). 
10. Farida I., Setiawan R., Maryatmi A.S., Juwita M.N. The Implementation of E-Government in The Industrial Revolution Era 4.0 in Indonesia. International Journal of Progressive Sciences and Technologies. 2020;22(2):34-346.

11. Setiawan R. Partisipasi Publik Dalam Program Bantuan Listrik Pedesaan Masyarakat Kabupaten Mesuji. Jurnal e-JKPP. 2017;3(3):82-92 (In Indon.).

12. Setiawan R., Melinda E. Optimization of the Implementation of Village Government in Indonesia. RUDN Journal of Public Administration. 2020;7(4):352-360.

13. Setiawan R. Evolution of Tatarstan's Local Self-Governments and Challenges They Face. 'Adalah. 2019;3(5):16-34.

14. Setiawan R., Abdurahman A., Pertiwi, P. G., Saputri, S. Reaksi Perekonomian Rusia Ditengah Pandemi Covid-19. 'Adalah. 2020;4(1) (In Indon.).

15. Farida I., Setiawan. Leadership in Cope With Prostitute in Social Department of Bandar Lampung. International Journal of Social Sciences And Development. 2018;2(1):1-8. DOI: http://dx.doi.org/10.24967/saburaiijssd.v2i1

16. Borum R. Radicalization into Violent Extremism I: A Review of Social Science Theories. Journal of Strategic Security. 2011;4(4):7-36. DOI: http://dx.doi.org/10.5038/1944-0472.4.4.1

17. Borum R. Radicalization into Violent Extremism II: A Review of Conceptual Models and Empirical Research. Journal of Strategic Security. 2011;4(4):37-62 DOI: https://dx.doi.org/ 10.5038/1944-0472.4.4.2

18. McCauley C. The ABC Model: Commentary from the Perspective of the Two Pyramids Model of Radicalization. Journal Terrorism and Political Violence. 2020;17(6):39-64. DOI: https://doi.org/10.1080/09546553.2020.1763964

19. Rohmatika R.V., Hakiki K.M. Fanatisme Beragama Yes, Ekstrimisme Beragama No; Upaya Meneguhkan Harmoni Beragama Dalam Perspektif Kristen. Al-Adyan: Jurnal Studi Lintas Agama. 2018;13(1):1-22. DOI:https://doi.org/10.24042/AJSLA.V13I1.2940 (In Indon.).

20. McGregor I. Zeal, Identity, and Meaning: Going to Extremes to Be Oneself. Handbook of Experimental Existential Psychology. T.P.J. Greenberg, S.L. Koole (eds.). Guilford Press; 2004. URL: https://psycnet.apa.org/record/2004-21900-012

21. Hogg M.A., Adelman J.R., Blagg R.D. Religion in the Face of Uncertainty: An UncertaintyIdentity Theory Account of Religiousness. Personality and Social Psychology Review. 2010;14(1):72-83. DOI: https://doi.org/10.1177/1088868309349692

22. Kinnvall C. Globalization and Religious Nationalism: Self, Identity, and the Search for Ontological Security. Political Psychology. 2004;25(5):741-767.

23. Delamater J.D., Myers D.J., Collett J.L. Social Psychology. 8th ed. Routledge; 2018. DOI: https://doi.org/10.4324/9780429493096

24. Setiawan R., Sulthan M.F., Abdurrahman A. Government Policy in Public Services in the Republic of Tatarstan, Russia. Jurnal Cita Hukum. 2020;8(3):553-566.

25. Buana, D. R. Bagaimana ISIS Dapat Muncul dari Agama yang Memiliki Ajaran Menjadi Rahmat Bagi Seluruh Alam?. Adalah : Buletin Hukum \& Keadilan'. 2020;4(2):21-28. DOI: http://www.journal.uinjkt.ac.id/index.php/adalah/article/view/15266 (In Indon.).

26. Bovin B.G., Moskvitina M.M., Bovina I.B. Radicalization of women: an explicative potential of social psychological knowledge. Journal of Modern Foreign Psychology. 2020;9(3):97-108. DOI: https://doi.org/10.17759/jmfp.2020090309

27. Brugh C.S., Desmarais S.L., Simons-Rudolph J., Zottola S.A. Gender in the Jihad: Characteristics and Outcomes among Women and Men Involved in Jihadism-inspired Terrorism. Journal of Threat Assessment and Management. 2019;6(2):76-92. DOI: https://doi.org/10.1037/TAM0000123

28. Wickham B.M., Capezza N.M., Stephenson V.L. Misperceptions and Motivations of the Female Terrorist: A Psychological Perspective. Journal of Aggression, Maltreatment, \& Trauma. 2019;29(8):953-968. DOI: https://doi.org/10.1080/10926771.2019.1685041

29. Bovin B.G., Moskvitina M.M., Bovina I.B. Radicalization of Women: An Explicative Potential of Social Psychological Knowledge. Journal of Modern Foreign Psychology. 2020;9(3):97-108. DOI: https://doi.org/10.17759/jmfp.2020090309

30. Spencer A.N. The Hidden Face of Terrorism: An Analysis of the Women in Islamic State. Source: Journal of Strategic Security. 2016;9(3):74-98. DOI: https://doi.org/10.2307/26473339

31. Goldman L., Hogg M.A. Going to Extremes for One's Group: The Role of Prototypicality and Group Acceptance. Journal of Applied Social Psychology. 2016;46(9):544-553. DOI: https://doi.org/10.1111/JASP.12382 
32. Wilner A.S., Dubouloz C.-J. Homegrown Terrorism and Transformative Learning: An Interdisciplinary Approach to Understanding Radicalization. Global Change, Peace \& Security. 2010;22(1):33-51. DOI: https://doi.org/10.1080/14781150903487956

Information about the authors:

Dana Riksa Buana - PhD Student of Psychological Science, Tomsk State University (Russian Federation) (ORCID ID: 0000-0003-0516-1703) (e-mail: dana.riksabuana@gmail.com).

Masayu Nila Juwita - Lecturer in the Department of Public Administration, University of Bandar Lampung (Indonesia) (ORCID ID: 0000-0002-3278-2188) (e-mail: masayu@ubl.ac.id).

\title{
Политика правительства по борьбе с религиозным экстремизмом в Индонезии: междисциплинарный обзор на основе государственного управления и психологии
}

\author{
Д.Р. Буана ${ }^{1} \mathbb{D} \backsim$, М.Н. Джувита ${ }^{2}$ \\ ${ }^{1}$ Томский государтсвеннй университет, \\ 634050, Россия, Томск, пр. Ленина, 36 \\ ${ }^{2}$ Университет Бандар-Лампунг, \\ 35142, 3.А. Индонезия, Лампунг, Лабухан Рату, ул. Пагар, 29 \\ $\triangle$ dana.riksabuana@gmail.com
}

\begin{abstract}
Аннотация. Религиозный экстремизм в Индонезии продолжает нарастать с каждым годом, поэтому правительству страны требуется обращать серьезное внимание на борьбу с этим явлением. Индонезия - страна-архипелаг, где сосуществуют различные этнические группы и религии. Однако развитие религиозного экстремизма становится серьезной проблемой для индонезийского народа, поскольку может иметь негативные социально-политические последствия и разрушить единство между нациями и религиями. В данном исследовании показано, что не все формы и проявления религиозного экстремизма влияют на возникновение терроризма, но правительство все же должно проводить правильную политику в отношении религиозного экстремизма, который может вызвать раскол бщества и негативно повлиять на благосостояние людей. Авторы утверждают, что политика, проводимая правительством Индонезии, является достаточно эффективной и основана на праве и, таким образом, оказывает положительное влияние на поддержание единства и целостности индонезийской нации.
\end{abstract}

Ключевые слова: государственная политика, религиозный экстремизм, единство сообщества, терроризм, Индонезия

Заявление о конфликте интересов: Авторы заявляют об отсутствии конфликта интересов.

История статьи:

Статья поступила в редакцию: 09.08.2021. Статья принята к публикации: 25.09.2021.

\section{Для цитирования:}

Buana D.R., Juwita M.N. Government Policy in Overcoming Religious Extremism in Indonesia: A Multidisciplinary Review between Public Administration and Psychology // Вестник Российского университета дружбы народов. Серия: Государственное и муниципальное управление. 2021. T. 8. № 4. C. 423-433. DOI: 10.22363/2312-8313-2021-8-4-423-433

\section{Информация об авторах:}

Дана Рикса Буана - аспирант Томского государственного университета (ORCID ID: 00000003-0516-1703) (e-mail: dana.riksabuana@gmail.com).

Масаю Нила Джувита - преподаватель кафедры государственного управления Университета Бандар-Лампунг (Индонезия) (ORCID ID: 0000-0002-3278-2188) (e-mail: masayu@ubl.ac.id). 